\title{
POCZĄTKI KOŚCIOŁA W ŁĘCZYCY. BADANIA OPACTWA I KOLEGIATY W TUMIE POD ŁĘCZYCĄ
}

\author{
THE BEGINNINGS OF THE CATHOLIC CHURCH IN ŁECCZYCA. \\ EXCAVATIONS OF THE ABBEY AND THE COLLEGIATE CHURCH IN TUM
}

The paper summarises excavations and conservation works at the $12^{\text {th }}$-century collegiate church of St. Mary and St. Alexius in Tum near Łęczyca and the foundation walls relics uncovered under the church which are identified with St. Mary's abbey, mentioned in the Gniezno bulla from 1136. The presumably Benedictine abbey could have been built around the year 1000 and was pulled down before erection of the collegiate church, which started around 1141. After several destructions and reconstructions that took place during the 850 years of existence, the church has recently undergone conservation procedures to allow its further functioning.

KEY WORDS: Łęczyca, Tum, collegiate church, abbey, Early Middle Ages

W wydanych w 1995 r. „Pamiętnikach” profesor Konrad Jażdżewski, założyciel łódzkiego ośrodka archeologicznego, tak wspominał łódzkie początki badań nazywanych dziś milenijnymi, a w szczególności badania w Tumie pod Łęczycą:

„(...) Otóż na kilka lat wcześniej przed tą datą [1948 r.] dr Witold Hensel, jeden z najwybitniejszych uczniów prof. J. Kostrzewskiego, wraz z gronem innych badaczy zajmujących się wczesnośredniowieczną kulturą Polski, rzucił myśl, by uczcić 1000-lecie państwowości polskiej szeroko zakrojoną akcją badawcza, której celem byłoby lepsze niż dotychczas ukazanie dziejów i kultury ziem polskich w drugiej po- łowie I tysiąclecia po Chr. (...) Myśl ta, wyrażona w kilku publikacjach, trafiła na szczęście na grunt podatny u czynników kierujących ex officio życiem kulturalnym kraju i w ślad za tym zaczęto wspierać materialnie i organizacyjnie na szeroką skalę badania archeologiczne $\mathrm{i}$ inne $\mathrm{z}$ dziedziny nauk pokrewnych w całym kraju. Jeszcze wcześniej, zanim ta oficjalna, odgórna akcja została rozpoczęta, przygotowywałem się do tego, by w oparciu o zasoby materialne, sprzęt i personel, jakim dysponowały instytucje łódzkie, którymi kierowałem (Miejskie Muzeum Prehistoryczne i Katedra Prehistorii UŁ), rozpocząć badania dwóch obiektów 
wczesnośredniowiecznych w regionie łódzkim: grodziska w Tumie pod Łęczycą, a w rok później cmentarzyska w Lutomiersku (...) Uzyskałem zgodę na włączenie do ogólnopolskiego programu badawczego wspomnianego wyżej wczesnośredniowiecznego stanowiska w Tumie pod Łęczycą (dawnej Łęczycy), ale zobligowano - i to przede wszystkim - do podjęcia badań w Gdańsku. Jak widać - program badawczy, mający być zrealizowany równocześnie przez łódzki ośrodek archeologiczny był bardzo napięty i zachodziła obawa czy podołamy tylu przedsięwzięciom naraz przy tym stanie liczebnym i jakościowym ośrodka, jaki on przedstawiał w tym czasie. (...) Ogólnym szefem całości tych przedsięwzięć badawczych byłem sam, a moimi zastępcami byli: mgr Janina Kamińska (wówczas jeszcze w Gdańsku) i mgr Andrzej Nadolski (w Tumie-Łęczycy)." (Jażdżewski 1995, 239-240).

Jak napisał profesor Jażdżewski, badania na grodzisku w Tumie rozpoczęły się w 1948 r., a od 1949 r. prowadzone były w ramach Kierownictwa Badań nad Początkami Państwa Polskiego, zaś po powstaniu Instytutu Historii Kultury Materialnej
PAN przez Zakład Archeologii Polski tegoż Instytutu.

Badacze grodziska mieli codzienny widok na monumentalną romańską kolegiatę, oddaloną od miejsca ich pracy, ale też i zamieszkiwania (barak na majdanie grodziska) o 400-500 $\mathrm{m}$ w linii prostej (ryc. 1).

Kolegiata była wówczas mocno uszkodzona przez polską artylerię, która 10 września 1939 r., podczas Bitwy nad Bzurą, była zmuszona zlikwidować niemiecki posterunek obserwacyjny, ulokowany na jednej z wież kościoła. Rozkaz ostrzelania kolegiaty wywołał wprawdzie konsternację oficerów i pozostałych żołnierzy, którzy dobrze zdawali sobie sprawę ze szkód, jakie w ten sposób wyrządzą, ale oczywiście został wykonany. Rozbito szczyt północnej wieży, a pożar wywołany przez ostrzał objął całą budowlę. Spłonął hełm północnej wieży i drewniane wiązania w jej wnętrzu, zawaliły się przepalone dachy trzech naw, prezbiterium, apsyd i baszt.

W efekcie tych działań, a i zrozumiałych zaniechań podczas wojny, kolegiata $\mathrm{w}$ drugiej połowie lat 40. XX w. była w bardzo złym stanie technicznym i wymagała natychmiastowej konserwacji, remontu i rekonstrukcji. Dzieła tego podjął się profe-

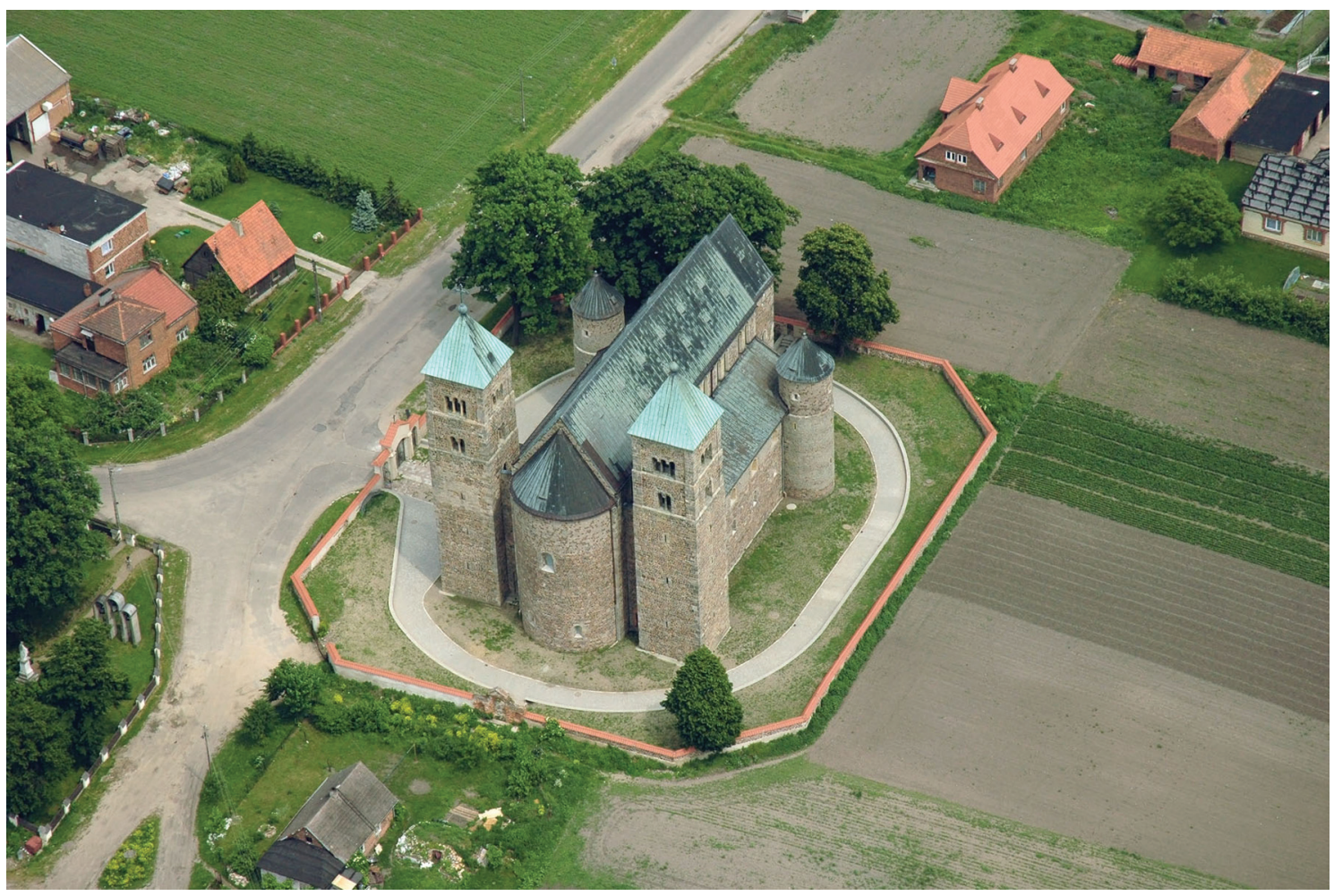

Ryc. 1. Kolegiata w Tumie pod Łęczycą. Widok z lotu ptaka od południowego wschodu. Fot. W. Stępień Fig. 1. The collegiate church in Tum (by Łęczyca). Aerial view from the South-East. Photo W. Stępień 


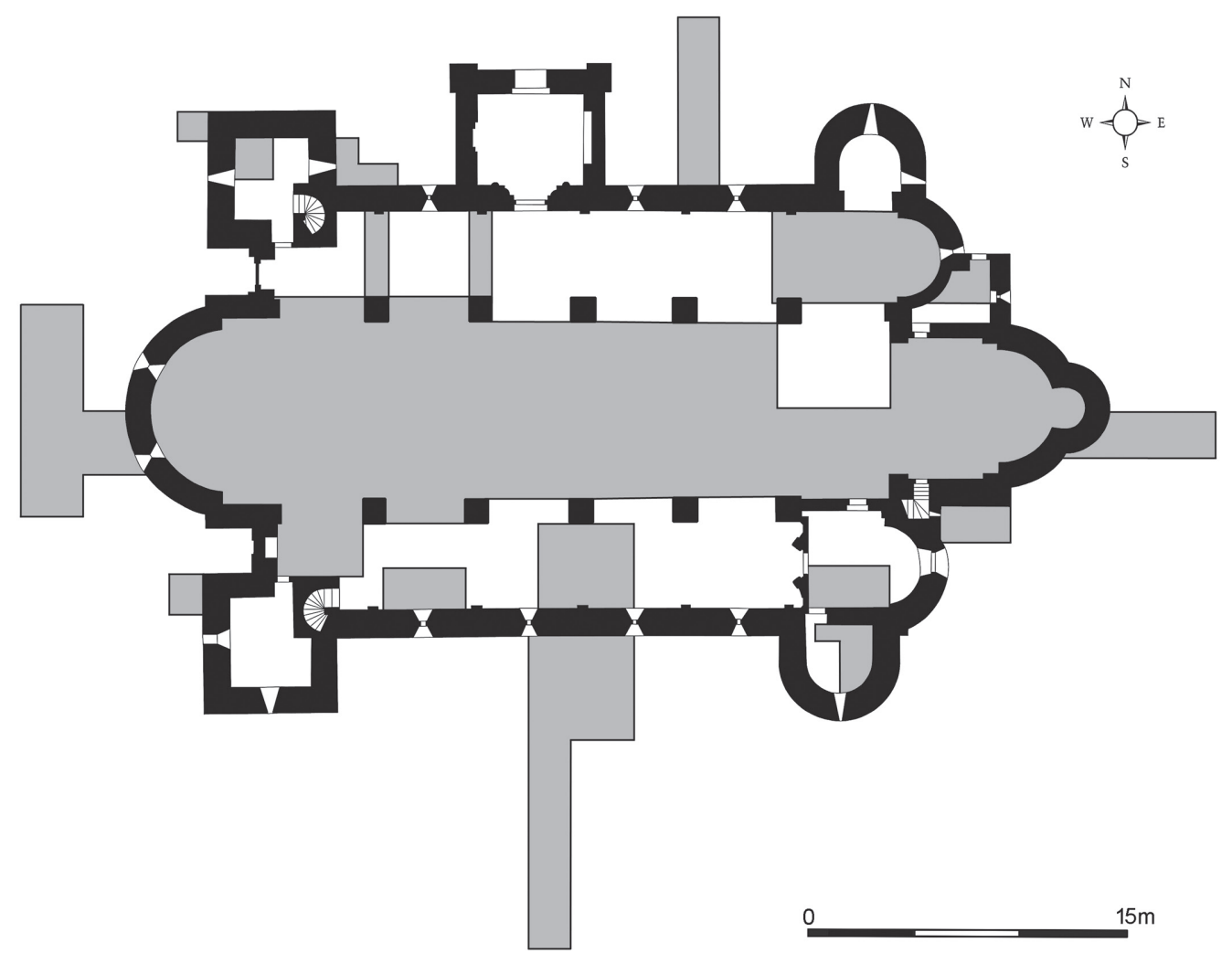

Ryc. 2. Kolegiata w Tumie pod Łęczycą. Plan wykopów z lat 50. XX w. Wg: Nadolski et al. 1960. Opr. komp. E. Wtorkiewicz-Marosik

Fig. 2. The collegiate church in Tum. Plan of trenches from the 1950s. From Nadolski et al. 1960. Digitalized by E. Wtorkiewicz-Marosik

sor Jan Koszczyc-Witkiewicz, który - z ramienia Generalnego Konserwatora Zabytków - kierował od 1948 r. pracami w kolegiacie. Wspomnieć tu należy, że profesor nie doczekał finalizacji prac, zmarł bowiem w 1958 r., jeszcze przed ich zakończeniem.

Już na samym początku prac konserwatorskich rozpoczęto współpracę $\mathrm{z}$ archeologami pracującymi na grodzisku, gdyż w północnej baszcie odkryto bogato wyposażony grób duchownego.

Natomiast do planowych wykopalisk w kolegiacie doszło w $1954 \mathrm{r}$. i prowadzono je do $1958 \mathrm{r}$. Ogólne kierownictwo badań w kolegiacie sprawował doc. Andrzej Nadolski, zaś prace w wykopach prowadzili mgr Andrzej Abramowicz i mgr Tadeusz Poklewski. Ze względu na specyfikę badań zaproszono do współpracy historyków architektury, którymi kierowali mgr inż. Zdzisław Tomaszewski i mgr inż. Antoni Kąsinowski. Ścisłą współpracę prowadzono oczywiście z prof. J. KoszczycWitkiewiczem (Nadolski et al. 1960, 5-10).
Wykopami archeologicznymi objęto niemal całą nawę główną, prezbiterium i obie apsydy, a także pewne partie naw bocznych, wież i baszt. W kilku miejscach zbadano także najbliższe otoczenie kolegiaty (ryc. 2).

Już w pierwszym sezonie badań odkryto narożnik starszej budowli kamiennej, niepowiązanej z kolegiatą, którą od początku identyfikowano ze znanym ze źródeł opactwem Najświętszej Marii Panny. W dalszych sezonach odsłonięto praktycznie cały rzut tej budowli (ryc. 3). Badania przyczyniły się także do szeregu odkryć rzucających nowe światło na dzieje kolegiaty. A zatem zaobserwowano ślady jej romańskiej przebudowy, zarejestrowano relikty gotyckiego lektorium, odkryto szereg romańskich detali architektonicznych zalegających w wykopach, a wreszcie 176 grobów ze szkieletami ułożonymi w porządku anatomicznym i olbrzymią liczbę luźnych kości ludzkich. Tylko jeden z grobów pochodził z czasów funkcjonowania starszej budowli, nieliczne $\mathrm{z}$ początkowych, romańskich 


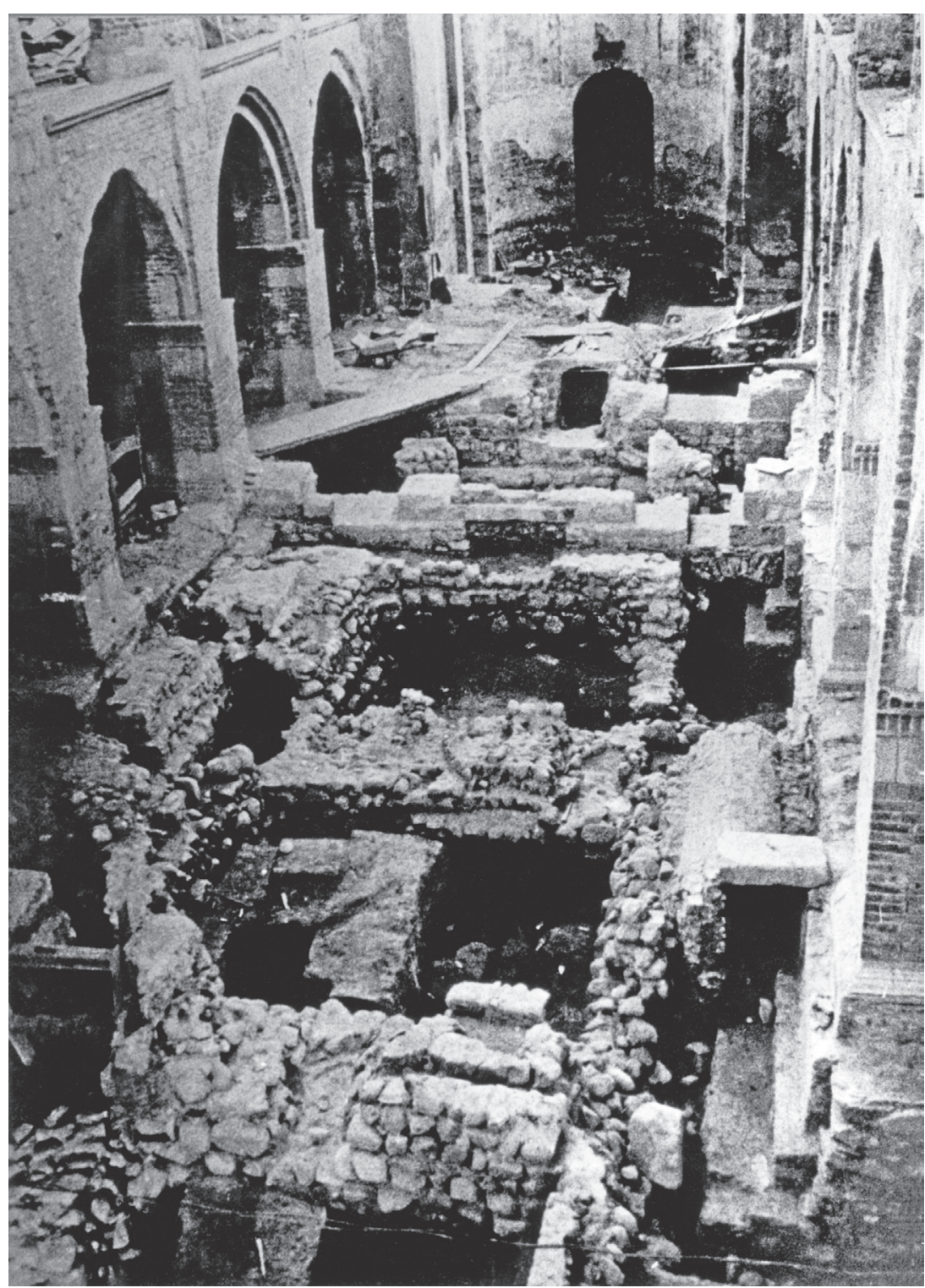

Ryc. 3. Widok wykopu w nawie głównej kolegiaty w Tumie pod Łęczycą z fundamentami opactwa.

Wg: Nadolski et al. 1960.

Opr. komp. E. Wtorkiewicz-Marosik Fig. 3. A view of a trench in the central aisle of the collegiate church in Tum with the excavated foundation walls of the abbey. From Nadolski et al. 1960. Digitalized by E. Wtorkiewicz-Marosik faz kolegiaty, w tym kilka bogato wyposażonych grobów dostojników kościelnych, a znakomita większość z późnego średniowiecza i nowożytności (Nadolski et al. 1960, 13-43).

Odkrycie w obrębie kolegiaty starszej budowli było niewątpliwą sensacją, zwłaszcza że natychmiast powiązano ją z opactwem Najświętszej Marii Panny wymienionym w bulli gnieźnieńskiej z 1136 r., w której napisano m.in.: ...Item abbatia sancte Marie in castello Lancicie cum centum servis et villis eorum, cum quatuor scilicet lacubus: Pretche, Chotle, Bezdeze, Brdovo (Bulla z 1136 r.). Określenie tej budowli jako sakralnej było dość oczywiste - nie dość, że zbudowano ją z kamienia, to była zorientowana i zakończona apsydą. Jednak stwierdzone wewnętrzne podziały wykluczyły, że mogłyby to być relikty kościoła (ryc. 4).
Przypomnijmy zatem najważniejsze fakty, które pozwoliły na taką właśnie interpretację odkrycia. Obiekt zbudowany został na terasie około $3 \mathrm{~m}$ wyższej niż sąsiednie tereny zalewowe, w obrębie istniejącej tam osady, w miejscu zniszczonym wcześniej przez pożar. Z miejsca, gdzie miano wznosić mury, usunięto warstwy, które odłożyły się podczas funkcjonowania osady, wykopano wąskoprzestrzenne wykopy fundamentowe, a po wzniesieniu murów około $1 \mathrm{~m}$ ponad ówczesny poziom podsypano je zarówno wewnątrz, jak i na zewnątrz.

Mury zostały wzniesione $\mathrm{z}$ kamieni polnych, oblicowano je z zewnątrz i wewnątrz kostką granitowa, a w narożnikach ciosami piaskowcowymi, czyli w wattku petit appareil. Stwierdzono, że cały budynek na planie prostokąta, zakończony od wschodu apsyda, podzielony jest na 4 pomieszcze- 


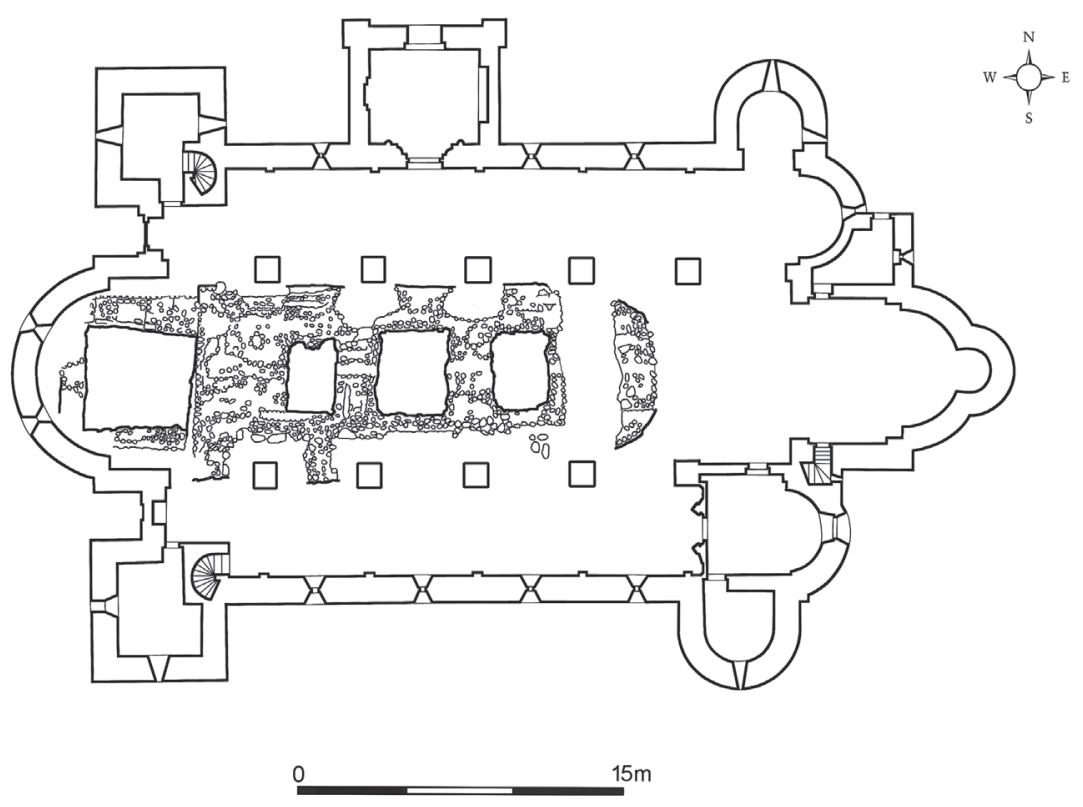

Ryc. 4. Rzut przyziemia kolegiaty w Tumie pod Łęczycą na tle rzutu opactwa. Wg: Żemigała (ed.) 2011. Opr. komp. E. Wtorkiewicz-Marosik

Fig. 4. The plan view of the ground floor of the collegiate church in Tum shown at the background of the abbey's ground plan. From Żemigała (ed.) 2011. Digitalized by E. Wtorkiewicz-Marosik

nia, przy czym skrajne, zachodnie, zostało dobudowane później. Całkowita długość starszego założenia, bez dobudówki, wynosiła 21,6 m, szerokość na poziomie fundamentów $9,0 \mathrm{~m}$, a na poziomie przyziemia $-7,20 \mathrm{~m}$. Długość bez apsydy wynosiła $18,0 \mathrm{~m}$, zewnętrzny promień apsydy $3,60 \mathrm{~m}$, wewnętrzny 2,4 m, zaś grubość murów - 1,2 m. Podaję te wymiary nie tylko dla porządku, bo wygląda na to, że przy rozmierzaniu budowli zastosowano stopę rzymską równą $30 \mathrm{~cm}$, a podstawowy moduł wynosił 2 stopy (Nadolski et al. 1960, 44-66).

Założenie, że opisywany obiekt pełnił funkcję sakralną, lecz nie był kościołem, wiązał go w sposób oczywisty z opactwem z bulli gnieźnieńskiej. Wychodząc $\mathrm{z}$ tego założenia, można było określić funkcję poszczególnych pomieszczeń. Częścią sakralna - kaplica - byłoby oczywiście pomieszczenie wschodnie, zakończone apsydą, określone przez badaczy jako pomieszczenie 1. Kolejnymi byłyby: kapitularz - pomieszczenie 2 i refektarz - pomieszczenie 3 (ryc. 5). W przyziemiu brak zatem miejsca na dormitorium i celę opata. Ponieważ podczas wykopalisk nie stwierdzono, aby budowla mogła być podpiwniczona, a jednocześnie mury mają znaczną grubość, badacze opactwa przyjęli, że było ono co najmniej dwukondygnacyjne, a w kondygnacji, czy w kondygnacjach wyższych znalazłyby się pomieszczenia sypialne mnichów. Budynek jednotraktowy wymagał co najmniej dwóch wejść, które odkrywcy hipotetycznie umieścili w południowej ścianie, kierując się szeroką na 1,8 m zewnętrzną odsadzka, ponad którą mógł się zmieścić nawet krużganek czy zamknięty korytarz. Schody na drugą kondygnację umieścili oni $\mathrm{w}$ pomieszczeniu 3 (refektarzu), ponieważ również tam stwierdzono szczególnie szerokie odsadzki.

Przy takiej rekonstrukcji opactwa poszczególne pomieszczenia miałyby następującą powierzchnię: kaplica $32 \mathrm{~m}^{2}$, z czego apsyda mieszcząca ołtarz $9 \mathrm{~m}^{2}$, kapitularz $17 \mathrm{~m}^{2}$, refektarz niemal $26 \mathrm{~m}^{2}$, plus powierzchnia zajmowana przez schody prowadzące na drugą kondygnację. Cała zatem powierzchnia mieszkalna $\mathrm{w}$ dolnej kondygnacji miałaby około $45 \mathrm{~m}^{2}$. Wydaje się, że podobnie można oceniać powierzchnię kondygnacji górnej, sypialnej (Nadolski et al. 1960, 44-66).

Nieco inaczej funkcję poszczególnych pomieszczeń T. Poklewski rekonstruował kilkadziesiąt lat później. W referacie Abbatia sancte Marie in Castello Lancicie, wygłoszonym w 1997 r. w Łowiczu, na konferencji „Święty Wojciech i wejście Polski do Europy przed dziesięcioma wiekami” napisał: 

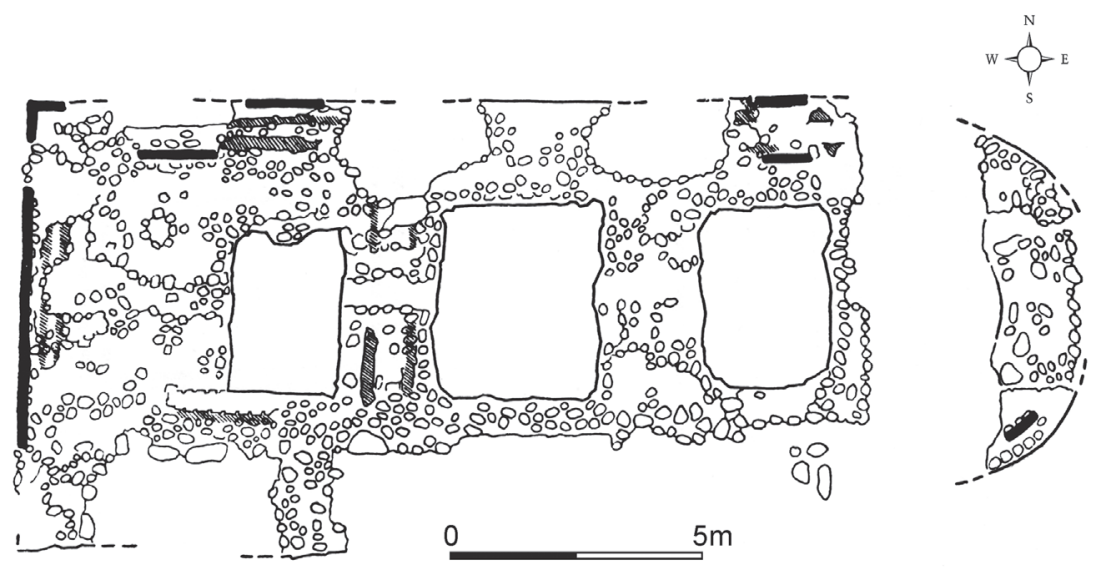

Ryc. 5. Rzut I fazy opactwa z zaznaczonymi fragmentami licowania ścian naziemnych. Wg: Nadolski et al. 1960. Opr. komp. E. Wtorkiewicz-Marosik

Fig. 5. The plan view of the 1 st phase of the abbey with fragments of the wall claddings marked. From Nadolski et al. 1960. Digitalized by E. Wtorkiewicz-Marosik

„...fakt zakończenia absydalnego w skrajnym pomieszczeniu wschodnim przesądza jego sakralny charakter, $\mathrm{z}$ dodatkowym podkreśleniem wymaganej liturgią orientacji, definiuje też funkcje pozostałych pomieszczeń w trakcie przyziemia. Przy kaplicy byłaby zatem zakrystia, a za nią w jednym ciagu kapitularz. Druga kondygnacja mieściłaby najpewniej dormitoria i salę rekreacyjną oraz locum opata. Refektarz wraz z kuchnią mogłyby ewentualnie mieścić się w dobudowanym skrzydle drewnianym. Rozszerzony fundament południowej ściany budowli sugeruje jakieś otwarcie i rozbudowę założenia w kierunku południowym. Jesteśmy zatem przekonani, iż odkopane relikty budowli starczały do pomieszczenia małego konwentu i zapewniały możliwość prawidłowej dyslokacji wszystkich podstawowych funkcji klasztornych.” (Poklewski-Koziełł 1997, 76-77).

Opactwo to zostało powiększone przez dobudowanie od strony zachodniej dodatkowego pomieszczenia o wymiarach zewnętrznych $9 \times 6 \mathrm{~m}$ i powierzchni wewnętrznej równej około $35 \mathrm{~m}^{2}$ (ryc. 6). Oznacza to, że ta część budowli była szersza niż pierwotne założenie i szerokość ta była równa szerokości budowli wraz z ewentualnym krużgankiem, czy korytarzem, teraz już może murowanym, usytuowanym od strony południowej. Rozbudowa budynku opactwa mogła się wiązać z powiększeniem konwentu, jednak trudno odgadywać, jaką funkcję owo pomieszczenie pełniło (Nadolski et al. 1960, 58-60).

W czasie badań archeologicznych nie znaleziono jakichkolwiek śladów zniszczenia opactwa, wręcz przeciwnie, wydaje się, że zostało ono celowo i w określonym porządku rozebrane, a kamienie wykorzystano podczas budowy kolegiaty (Poklewski-Koziełł 1997, 71-72).

Jest oczywiste, że musiało się to stać przed rozpoczęciem budowy kolegiaty, które zazwyczaj umieszcza się około $1141 \mathrm{r}$. Natomiast początek jego budowy nie może być starszy niż wprowadzenie w Polsce chrześcijaństwa. To są daty graniczne. Założenie, że opactwo powstało równocześnie z przyjęciem chrztu, jest mało prawdopodobne. Raczej należałoby początek opactwa umieścić około roku 1000, czyli w okresie wzmożonego rozwoju organizacji kościelnej państwa piastowskiego, a mnichami, którzy osiedli w Łęczycy, musieli być benedyktyni. Tezę taką postawili odkrywcy opactwa i autorzy publikacji z 1960 r. i podtrzymywali ja zawsze (ryc. 7). Opierali się na analogiach architektonicznych, pierwotnie głównie na dziesiątowiecznym opactwie św. Bawona z Gandawy, później też na innych oraz na źródłach pisanych, np. dokumencie Ottona III z 1001 r., wystawionym w Rawennie, w którym wśród innych świadków jest wymieniony Anastasius abbas monasterii sancte Marie Sclavenensis provincie. Ponieważ obecność dwu opactw pod wezwaniem Najświętszej Marii Panny w prowincji słowiańskiej, czyli w Polsce, w 1001 r. wy- 

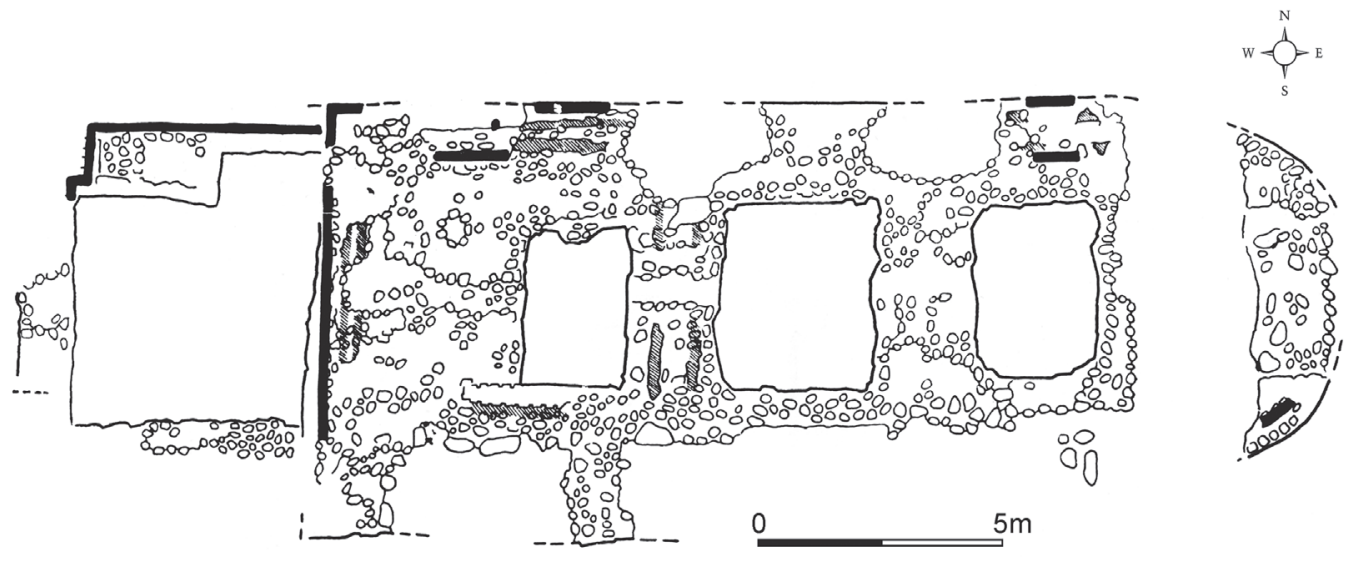

Ryc. 6. Rzut II fazy opactwa z zaznaczonymi fragmentami licowania ścian naziemnych.

Wg: Nadolski et al. 1960. Opr. komp. E. Wtorkiewicz-Marosik

Fig. 6. The plan view of the 2nd phase of the abbey with fragments of the wall claddings marked.

From Nadolski et al. 1960. Digitalized by E. Wtorkiewicz-Marosik

daje się mało prawdopodobna, przyjęli, że chodzi tu o opactwo łęczyckie (Nadolski et al. 1960, 71).

Odkrycie starszej budowli w Tumie pobudziło część badaczy do sformułowania innych interpretacji. Część z nich szła w kierunku uznania odsłoniętych reliktów za pozostałości palatium monarszego lub biskupiego (m.in.: Rozpędowski 1962; Pietrusińska 1971; Żurowska 1983; Morawski 2000). Inni uznawali wprawdzie odkryte fundamenty za resztki budowli sakralnej, jednak kwestionowali jej datowanie lub przeznaczenie na klasztor (m.in.: Zachwatowicz 1971; Świechowski 1990; Kajzer 1993; Pianowski 1994). Koncepcje te zestawił i skomentował J. Sikora i do jego artykułu pozwalam sobie odesłać zainteresowanych tymi problemami (Sikora 2002). Dodam, że sam J. Sikora opowiedział się za uznaniem reliktów odkrytych pod kolegiatą tumską za pozostałości jednonawowego kościoła klasztornego, prawdopodobnie benedyktynów, założonego w 2. poł. XI w., może rozbudowanego o zachodni aneks na przełomie XI i XII w. (Sikora 2002, 403-404).

Wracając do ustaleń odkrywców starszej budowli, przypomnę, iż zapiska z Bulli gnieźnieńskiej mówi o abbatiae sancte Marie in castello Lancicie. Tymczasem budowlę odkryto na osadzie oddalonej o 400-500 m od łęczyckiego grodu. Na nim zresztą nie było na nią miejsca. Dlatego słuszna wydaje się interpretacja mówiąca, że musiało chodzić o ,teren grodowy w sensie obszerniejszym, o własność książęcą w Łęczycy" (Nadolski et al. 1960,
70). Przypomnijmy też, że opactwo zbudowano na terenie osady datowanej archeologicznie na okres od 2. poł. X po XIII w. (Nadolski et al. 1960, 21). Prawdopodobieństwo, że osada mieszcząca się tuż koło wałów grodu nie miała nic z nim wspólnego, wydaje się nierealne.

Jakie były dalsze dzieje opactwa? Już w dużym skrócie: należy się liczyć z jego upadkiem raczej opuszczeniem niż zrujnowaniem - w $1038 \mathrm{r}$. (ryc. 7), albowiem trudno przyjąć, że właśnie Łęczyca, położona między spustoszoną przez Czechów Wielkopolską i pogańskim Mazowszem, wyszła z pogromu cało. Benedyktyni zapewne schronili się w znaczniejszym ośrodku władzy książęcej, podobnie jak mnisi z Międzyrzecza, którzy uciekli wraz z relikwiami Pięciu Braci do Gniezna. Reaktywowanie opactwa mogło nastąić około 1075 r., wraz z restauracją metropolii gnieźnieńskiej. Wtedy to doszłoby do jego rozbudowy, czyli co najmniej do dobudowania czwartego pomieszczenia w zachodniej części budowli. Ostateczny kres opactwa należy wiązać z jego przejściem na własność arcybiskupa gnieźnieńskiego, które zapewne nastąpiło około 1100 r. Od tego czasu opactwo jako instytucja już nie istniało, choć zabudowania, jak mówi bulla gnieźnieńska, stały i były własnością arcybiskupa (Nadolski et al. 1960, 72-74).

Wspomniałem już, że początek budowy kolegiaty datuje się na czasy około 1141 r., lecz czyni się to nie na podstawie przekazów źródłowych, lecz na podstawie przeświadczenia, że kościół taki, 


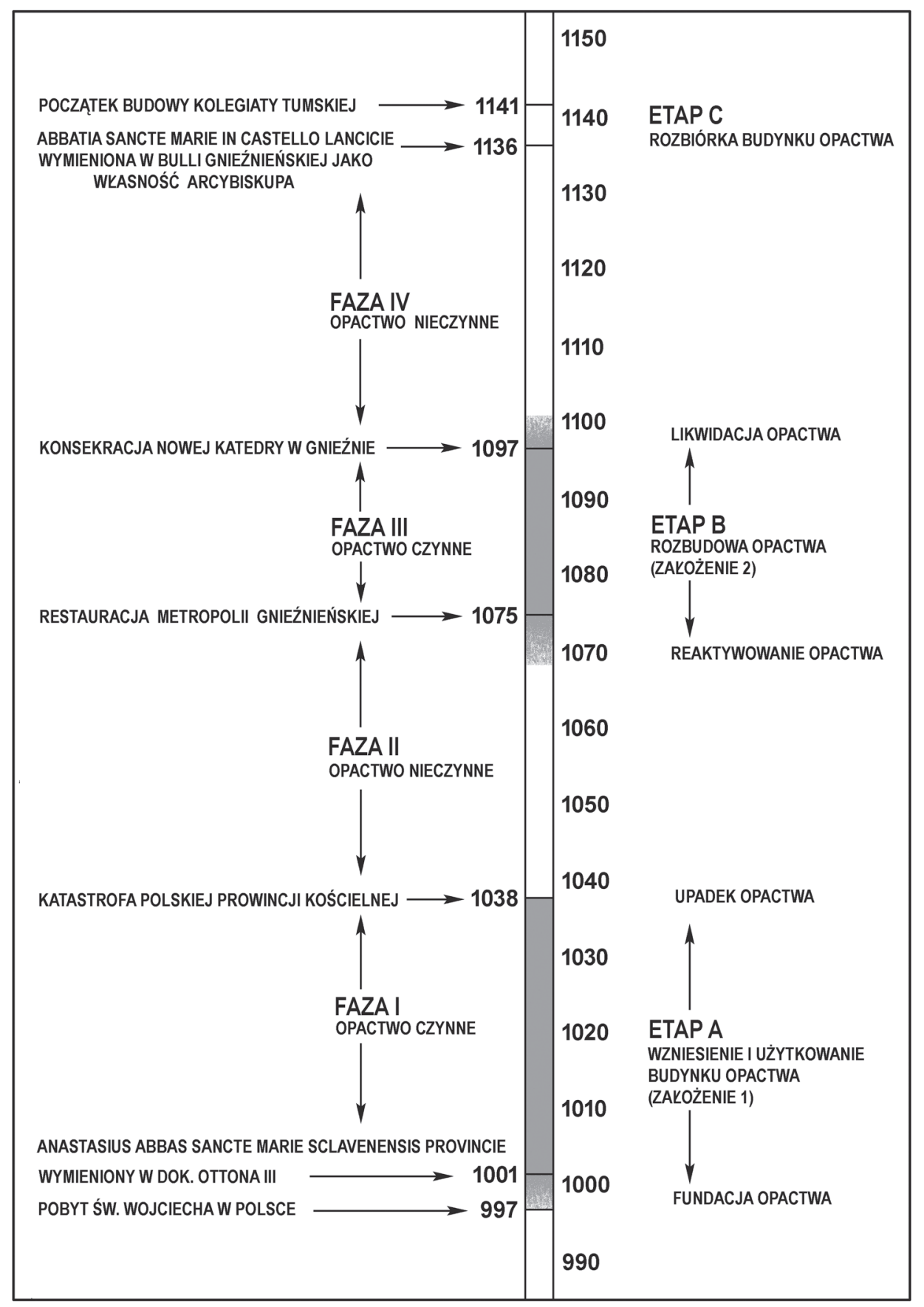

Ryc. 7. Schemat chronologii opactwa. Wg: Nadolski et al. 1960. Opr. komp. E. Wtorkiewicz-Marosik Fig. 7. An outline of the abbey's chronology. From Nadolski et al. 1960. Digitalized by E. Wtorkiewicz-Marosik

jak kolegiata tumska, budowano w średniowieczu około 20 lat. A data konsekracji jest znana - stało się to $\mathrm{w} 1161 \mathrm{r}$. Jeżeli budowę kolegiaty zaczęto istotnie na początku lat 40. XII w., to należałoby ją wiązać z tym, że Łęczyca została po śmierci Bolesława Krzywoustego wyodrębniona z dzielnicy senioralnej i przekazana księżnej Salomei. Na grodzie znajdował się jej dwór, w którym w $1140 \mathrm{r}$. przyjmowała opata benedyktyńskiego klasztoru z Zwiefalten (Szymczak 2011, 9-11; Tomaszewski 1997, 62-63).

Jednak prof. Andrzej Tomaszewski sądzi, że kolegiata mogła być postawiona w czasie krótszym niż 20 lat. Jest bowiem dziełem jednorodnym, wykonanym przez jeden warsztat budowlany. $\mathrm{W}$ takim wypadku fundatorem mógł być jeden $\mathrm{z}$ książąt juniorów, synów Salomei i Bolesława lub arcybiskup gnieźnieński Jakub ze Żnina (zm. 1148 r.), ewen- 
tualnie jego następca Jan, zwany Janikiem (zm. 1167 r.). Przypomnijmy, że w bulli gnieźnieńskiej zapisano, iż abbatia było własnością arcybiskupstwa. Dlatego, jeśli przyjąć krótszy niż dwudziestoletni czas budowy kolegiaty, to fundacja arcybiskupia wydaje się być wysoce prawdopodobna, choć pierwotny zamysł budowy mógł wyjść od księżnej (Szymczak 2011, 10-11; Tomaszewski 1997, 63). Tak czy inaczej, budowę kolegiaty rozpoczęto w pierwszej połowie, czy może w połowie lat 40 . XII w.

W tym miejscu należy wyraźnie zaznaczyć, że badania kolegiaty nigdy nie doczekały się takiego opracowania, jak badania opactwa. Stało się tak dlatego, że w międzyczasie Zdzisław Tomaszewski, prowadzący podstawowe badania architektoniczne, wyjechał na stałe z Polski i nie miał możliwości powrotu do niej. Z informacji uzyskanej niegdyś od profesora T. Poklewskiego wiem, że pozostali badacze nie czuli się na siłach, aby bez niego takie opracowanie wykonać. Kolegiata jednak pozostała w kręgu ich zainteresowań, a przede wszystkim w kręgu zainteresowań profesora Poklewskiego i wykorzystywał on wyniki tychże prac w wielu publikacjach.

Materiały z badań udostępniane były także innym badaczom. W pierwszym rzędzie należy tu wymienić Tomasza H. Orłowskiego, który przygotował pod kierunkiem prof. A. Nadolskiego prace magisterską na Uniwersytecie Łódzkim pt.: „Próba rekonstrukcji wnętrza romańskiej kolegiaty w Tumie pod Łęczycą z lat 1161-1294", opublikowaną w „Kwartalniku Architektury i Urbanistyki”, a także profesorów Andrzeja Tomaszewskiego i Zygmunta Świechowskiego (Orłowski 1983, 91-118; Tomaszewski 1997, 61-67; Świechowski 2011, 3136). Trzeba dodać, że wszyscy oni odwoływali się do fundamentalnej, jeszcze przedwojennej monografii kolegiaty autorstwa M. Walickiego (Walicki 1938).

Wyniki badań kolegiaty omówię zatem w największym skrócie. Jak już wyżej wspomniałem, przez rozpoczęciem budowy rozebrano bardzo starannie mury opactwa, a uzyskany z nich kamień wykorzystano przy budowie nowej świątyni. Następnie wykopano doły pod jej ściany i filary. Ziemię z wykopów usunięto na zewnątrz i najprawdopodobniej rozplantowano. W momencie, gdy fundamenty już były wyciągnięte nad ziemię, a może, gdy budowla była gotowa $\mathrm{w}$ stanie surowym, gruzem $\mathrm{z}$ opactwa zasypano szczeliny między fundamentami filarów a ścianami wykopów fundamentowych (Nadolski et al. 1960, 37-39).

Ostatecznie wzniesiono trójnawową bazylikę bez transeptu z dwiema apsydami (wschodnią i zachodnią), dwiema wieżami w zachodniej fasadzie budowli i dwiema okragłymi basztami w fasadzie wschodniej. W wielokondygnacyjnych wieżach znalazły się przezrocza o otworach przegrodzonych kolumienkami. Boczne nawy, z emporami, zakończone są od wschodu apsydami. Nawa główna ma od wschodu prezbiterium z apsydą, w której - na osi - jest mała apsydka. Nawa główna, z sześcioma przęsłami, przekryta była stropem, prezbiterium miało sklepienie kolebkowe, zaś apsydy przykryte były konchami. Nawy boczne przykrywało sklepienie krzyżowe, bez żeber. W nawach bocznych ołtarze stały w apsydach, także w nawie głównej umieszczone były dwa ołtarze odpowiadające dwom wezwaniom kolegiaty: Najświętszej Marii Panny i św. Aleksego. W portalu głównym, w północnej ścianie, umieszczono rzeźbiony tympanon przedstawiający adorację NMP z Dzieciątkiem, zaś w apsydzie zachodniej odkryto malowidło przedstawiające Sąd Ostateczny. Okna umieszczone zostały w trzech strefach: w nawie głównej, w nawach bocznych i w emporach. W dolnych partiach wież i baszt znajdują się szczeliny, pierwotnie traktowane przez badaczy i monografistów kolegiaty jako strzelnice nadające budowli obronny charakter (Nadolski 2001, 84) - ryc. 4.

Kolegiata, tak wyglądająca w przybliżeniu, choć może w szczegółach jeszcze niewykończona, została konsekrowana w dniu 21 maja 1161 r. Trzeba zauważyć, że data ta nie ma żadnego związku z wezwaniami jej nadanymi - Najświętszej Marii Panny i św. Aleksego. Według Jana Szymczaka zjazd władcy - Bolesława Kędzierzawego - z elita polityczną kraju, połączony z konsekracją świątyni zbudowanej jako wotum za zwycięstwo nad Władysławem II Wygnańcem, odbył się w związku z zagrożeniem interwencją cesarza Fryderyka I Barbarossy na rzecz synów księcia, zmarłego w 1159 r.

Do Łęczycy, wraz z princepsem Bolesławem Kędzierzawym, przyjechali jego dwaj młodsi bracia Henryk i Kazimierz, którzy otrzymali później przydomki-Sandomierski i Sprawiedliwy. Zamiast Mieszka Starego, dystansującego się od polityki starszego brata Bolesława, był prawdopodobnie jego pierworodny syn Otto. Duchowieństwo reprezentowali: arcybiskup gnieźnieński Janik, biskup krakowski Mateusz, wrocławski Walter i kruszwic- 
ki Onold. Wśród świeckich możnych wymienić należy w pierwszym rzędzie Jaksę - zięcia wojewody Piotra Włostowica oraz jego szwagra Świętosława, czyli syna Piotra Włostowica. Ogółem w kolegiacie łęczyckiej zebrało się 4 książąt, 5 biskupów i 26 wymienionych z imienia możnowładców. Wszystko to świadczy o wadze spotkania wynikającego $\mathrm{z}$ istotnego zagrożenia bezpieczeństwa państwa czy dynastii, ale też ze znaczenia aktu konsekracji kolegiaty (Szymczak 2011, 12-16).

Przy łęczyckiej świątyni osadzone zostało dwunastoosobowe zgromadzenie kanoników świeckich - najstarsze w Polsce, pozakatedralne, pełne monasterium kanonickie. W ten sposób kolegiata w Łęczycy stała się drugą po katedrze kościelną placówką w archidiecezji gnieźnieńskiej, ale też pierwszą po katedrach polskiej prowincji kościelnej (Tomaszewski 1997, 62).

Dlaczego tej wielkości i o takim znaczeniu kolegiata stanęła właśnie w Łęczycy? Wspominałem już o tym, że zamysł jej budowy mógł powstać w czasach, gdy Łęczyca była rezydencją księżnej Salomei, wdowy po Bolesławie Krzywoustym. Kształt architektoniczny świątyni nawiązuje do budowli nadreńskich, czyli ze stron rodzinnych księżnej. Co jednak spowodowało, że po śmierci matki w 1144 r. jej synowie zdecydowali się kontynuować wielką inwestycję w Łęczycy, która utraciła już swój rezydencjonalny charakter, tego nie wiemy (Tomaszewski 1997, 62-63).

Walory obronne kolegiaty łęczyckiej musiały nie być istotnie zbyt duże, albowiem 6 czerwca 1294 r. najazd Litwinów pod wodzą wielkiego księcia Witenesa spowodował nie tylko wielkie straty ludności zebranej tam z okazji Zielonych Świątek, ale także wywołał olbrzymi pożar, w wyniku którego zwaliło się sklepienie w prezbiterium i chyba też przegrody kolumnowo-filarowe między nawą główną i bocznymi emporami (Poklewski, Puget, Jaworowski 2001, 669; Szymczak 2011, 17).

Po tym pożarze kolegiatę odbudował w 2 . ćwierci XIV w. arcybiskup Jarosław Bogoria ze Skotnik, nadając budowli pewne cechy gotyckie. Nie zmieniła się jej zewnętrzna sylweta, natomiast we wnętrzu, przy utrzymaniu dwukondygnacyjności budowli, zachowano już ceglane trzony filarów między nawami, a w drugim od wschodu przęśle nawy głównej wybudowano lektorium, odkryte podczas wykopalisk. Prawdopodobnie również wtedy, w ostatnim przęśle wschodnim nawy południowej, wymurowano z cegieł zakrystię oraz włączono do niej przyziemie sąsiedniej wieży, likwidując w niej klatkę schodową (Poklewski, Puget, Jaworowski 2001, 669-670).

Kolejne zniszczenia wnętrza kolegiaty spowodował pożar, który wybuchł w 1473 r., a w czasie przeprowadzonego po nim remontu, zakończonego w 1487 r., wymieniono sklepienia w nawach bocznych oraz przebudowano triforia i - częściowo - prezbiterium. Prace te jednak prowadzono już w formie gotyckiej, które w efekcie zmieniły wygląd i charakter wnętrza świątyni. Także w późniejszych wiekach wykonano różne, mniejsze lub większe przebudowy i remonty, np. w 1569 r. została wybudowana kruchta osłaniająca romański portal, a w XVIII w. nastąpiła barokowa przebudowa kolegiaty (Szymczak 2011, 20-21; Tomaszewski 1997, 67).

Jako wielką przebudowę należy też potraktować działania prof. Jana Koszczyc-Witkiewicza, który podczas powojennych prac konserwatorskich dokonał reromanizacji i regotycyzacji świątyni i nadał jej formę będącą tworem jego wizji konserwatorskiej, formę, jakiej kolegiata nigdy w dziejach nie miała. Jednocześnie wzmocnienie murów i wprowadzenie do struktury budowli żelbetowych konstrukcji spowodowało, że stała się ona, jako źródło historyczne, w dużym stopniu niedostępna do dalszych badań (Tomaszewski 1997, 67).

Dlatego ważną dla poznania kolegiaty była, wspomniana już, praca magisterska T.H. Orłowskiego, w której, wykorzystując materiały z badań archeologicznych z lat 1954-1958, zaproponował własną wizję świątyni pierwszej, romańskiej (ryc. 8). W pracy zastrzegł, że nie wszyscy badacze muszą się z nią zgadzać, ale liczy na to, że przedstawiony w niej materiał może posłużyć jego następcom do dalszych przemyśleń (Orłowski 1984, 91118). O ile wiem, nie zaproponowano do tej pory nowej koncepcji.

Działania konserwatorskie J. Koszczyc-Witkiewicza uratowały wprawdzie kolegiatę przed popadnięciem w całkowitą ruinę, ale popełniono w nich szereg błędów, na skutek których, ale też na skutek tego, że konserwacji nie przeprowadzono do końca (to też niewątpliwy błąd), jej stan już po niecałych 40 latach został określony jako katastrofalny (Koss 2011, 37).

W związku z tym, z inspiracji biskupa łowickiego Alojzego Orszulika, w którego diecezji leży Łęczyca, doszło w latach 1995-2008 do nowej, prowadzonej w bardzo nowoczesny sposób akcji kon- 

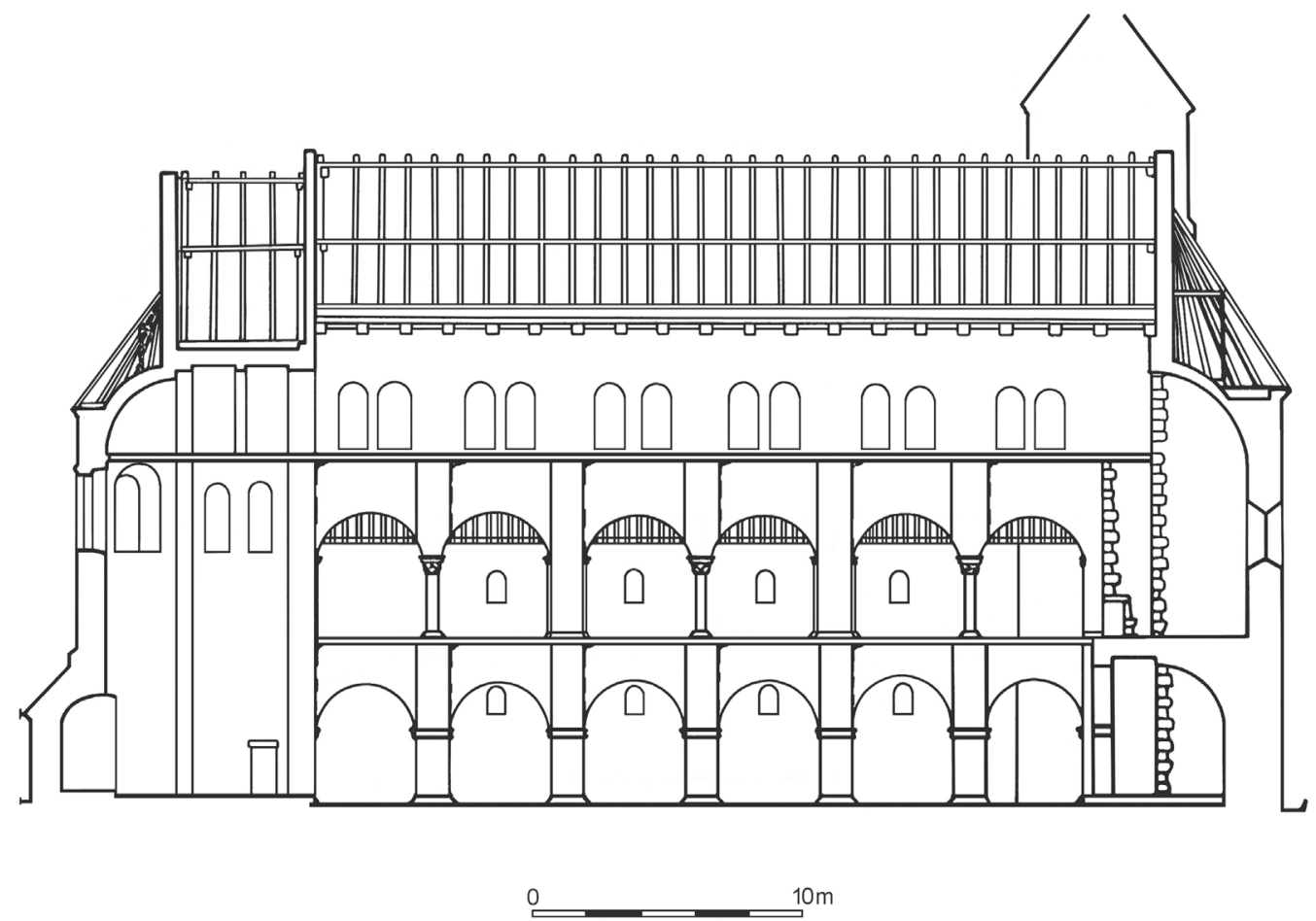

Ryc. 8. Rekonstrukcja romańskiej kolegiaty, przekrój W - E. Wg: Orłowski 1983. Opr. komp. E. Wtorkiewicz-Marosik Fig. 8. A reconstruction of the Romanesque collegiate church, W - E section. From Orłowski 1983.

Digitalized by E. Wtorkiewicz-Marosik.

serwatorskiej. Powołano zespół ekspertów, który przygotował program prac (prof. Maria Roznerska z Uniwersytetu Mikołaja Kopernika w Toruniu, dr Zenon Duda z Akademii Górniczo-Hutniczej w Krakowie, prof. Andrzej Koss z Akademii Sztuk Pięknych w Warszawie) i zespoły zajmujące się kolejnymi etapami prac. Do współpracy zaproszono wielu wybitnych specjalistów (np. prof. Zygmunta Świechowskiego, prof. Tadeusza Poklewskiego, prof. Jana Marczaka). Rozmiary tej pracy nie pozwalają na szczegółowe omówienie tych zabiegów, trzeba jednak podkreślić, że zatrzymano postępujący proces degradacji murów, detali architektonicznych, rzeźb i malowideł i doprowadzono świątynię do stanu, który powinien pozwolić na jej długie jeszcze funkcjonowanie. Wyniki tych prac zostały podsumowane na konferencji w 850-lecie konsekracji archikolegiaty w Tumie odbytej w Łęczycy w 2011 r. (Żemigała 2011).

Ta rocznica, ale i wcześniejsza - Zjazdu Gnieźnieńskiego i prawdopodobnie wynikająca $\mathrm{z}$ niego budowa opactwa, stały się inspiracją do powrotu zainteresowań problematyką najstarszych świątyń łęczyckich. W 1997 r. w Łowiczu odbyła się se- sja „Święty Wojciech i wejście Polski do Europy przed dziesięcioma wiekami” (Adamczyk 1997), w 2002 r. w XXV-lecie powołania Łęczyckiego Oddziału Towarzystwa Naukowego Płockiego opublikowano pracę zbiorową: „Pokłosie Zjazdu Gnieźnieńskiego. O początkach Kościoła w Łęczycy" (Solarski, Sęczkowska 2002), a w 2011 r. odbyła się wspomniana już sesja w 850-lecie konsekracji archikolegiaty w Tumie" (Żemigała 2011).

Rocznice te były także inspiracją do kontynuowania tumskich zainteresowań pracowników łódzkiego ośrodka Instytutu Archeologii i Etnologii PAN. Tu chciałbym wspomnieć o bardzo ciekawej, dobrze umotywowanej koncepcji, przewijającej się w pracach profesorów Andrzeja Tomaszewskiego i Tadeusza Poklewskiego, a mówiącej, że kształt kolegiaty wynikał z dostosowania jej do potrzeb liturgii procesyjnej, odprawianej przy siedmiu ołtarzach usytuowanych w apsydzie wschodniej nawy głównej, w nawie południowej, w apsydzie zachodniej, w nawie północnej, na trybunie nawy północnej, na trybunie nawy zachodniej i na trybunie nawy południowej (Poklewski 2011; Tomaszewski 1997, 65). 
Natomiast do mego własnego zaangażowania się w problematykę Tumu przyczyniło się znalezienie w jednym z grobów w kolegiacie, datowanym stratygraficznie na XVI w., kilkunastu fragmentów haftu, już na pierwszy rzut oka pochodzących z ornatu. Kompleksowe opracowanie tych znalezisk przekraczało moje możliwości. Dlatego doprowadziłem do powstania zespołu składającego się, oprócz mnie, z technologa włókiennictwa (Maria Cybulska z Politechniki Łódzkiej), chemika (Sławomir Kuberski z Politechniki Łódzkiej), historyka sztuki specjalizującego się w badaniu zabytkowych tkanin (Ewa Mianowska-Orlińska z Muzeum Narodowego w Warszawie) i historyka zajmującego się dziejami kapituły łęczyckiej (Anna Kowalska-Pietrzak z Uniwersytetu Łódzkiego).

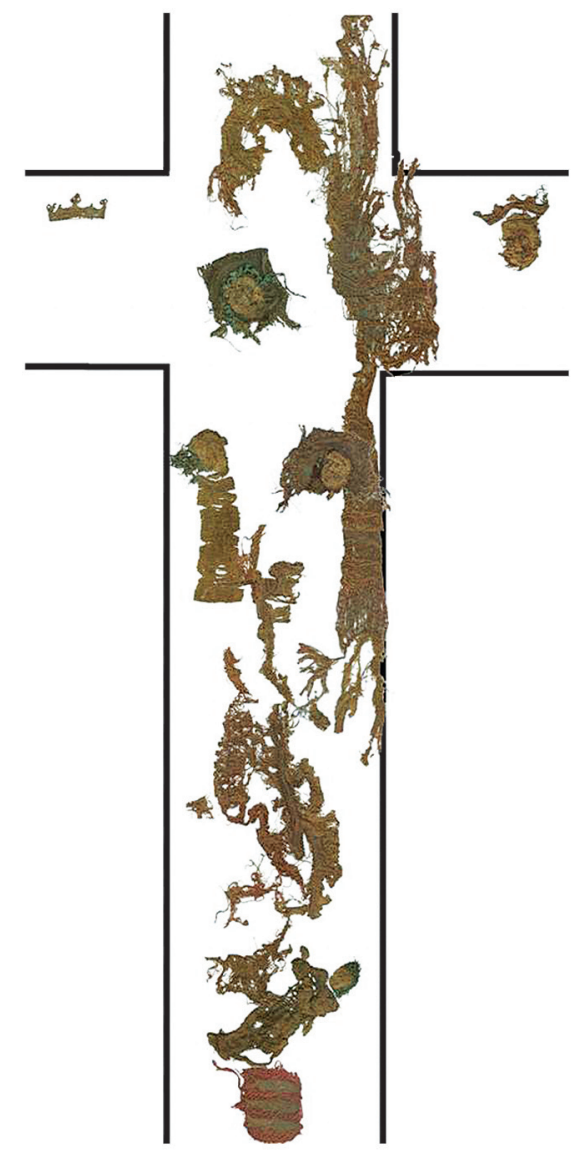

W efekcie wspólnej pracy udało się ustalić na podstawie analizy zachowanych resztek haftu oraz porównania ich ze średniowiecznymi szatami liturgicznymi, że pochodzą z preteksty XV-wiecznego ornatu przedstawiającego Drzewo Jessego. W centralnej partii jest scena ukrzyżowania, z której zachowała się spuszczona głowa Chrystusa oraz dwie postaci stojące pod krzyżem - Matka Boska i św. Jan. Ponad krzyżem zachował się nimb, w nim mogła być umieszczona głowa Boga Ojca. Głowa w koronie i korona przy ramionach krzyża mogą być pozostałościami sylwetek świętych dziewic, jakie często w takich wyobrażeniach umieszczano. Poniżej krzyża umieszczono hipotetycznie postacie św. Anny i św. Joachima - rodziców Matki Boskiej. Krzyż, który wraz z ornamentem wiciowym wi-

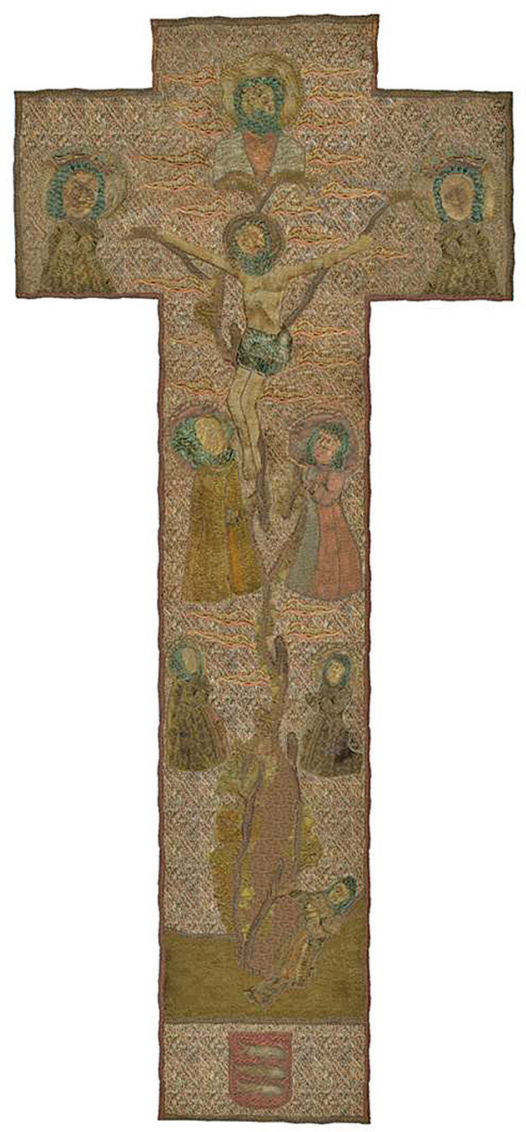

Ryc. 9. Preteksta ornatu z grobu w kolegiacie - układ zachowanych fragmentów oraz wizualizacja komputerowa. Wg: Cybulska et al. 2011

Fig. 9. A chasuble ophrey from the grave uncovered in the collegiate church - the arrangement of the preserved fragments and digital visualization. From Cybulska et al. 2011 
docznym w kilku miejscach tworzy Drzewo, wyrasta z leżącej postaci, właśnie Jessego. Według proroctwa $\mathrm{z}$ księgi Izajasza miał on być przodkiem Mesjasza.

Poniżej Jessego widoczny jest herb Korzbok (trzy ryby na czerwonym polu), którym pieczętował się Zygmunt z Kamieńca i Łęk, który na przełomie XV i XVI w. był duchownym związanym z kolegiatą w Tumie koło Łęczycy. W 1476 r. ubiegał się o kanonikat łęczycki, a w 1493 r. został tutejszym kustoszem. Był fundatorem ornatów dla katedry gnieźnieńskiej i poznańskiej. Może zatem ufundował dla kolegiaty łęczyckiej opisywany ornat. Nie został natomiast $\mathrm{w}$ nim pochowany, od 1517 r. mieszkał bowiem w Poznaniu, gdzie zmarł przed 1525 r. A kto spoczywał w kolegiacie w Tumie, w ornacie z wyobrażeniem Drzewa Jessego, chyba nigdy się nie dowiemy (Cybulska et al. 2011, 81-90) - ryc. 9.

Nawet jeśli uznać badanie resztek ornatu z Tumu za interesujący epizod poznawania dziejów łęczyckiej kolegiaty, to jednak jest to jedynie drobny epizod. Najważniejsze są badania archeologicznoarchitektoniczne, badania nad wystrojem świątyni czy jej konserwacja. Jak ocenić dotychczasowe poczynania, z tymi najstarszymi włącznie. Przypomnijmy zatem wątpliwości profesora Jażdżewskiego, czy zespół, którym dysponuje, poradzi sobie $\mathrm{z}$ badaniami grodziska oraz innych stanowisk przydzielonych łódzkiemu ośrodkowi archeologicznemu. Gdy do tych badań przystępowano, była w nim, oprócz Profesora, także mgr Janina Kamińska, a szlify magisterskie zdobywał Andrzej Nadolski, który w praktyce zaczął badaniami w Tumie kierować. Wszyscy oni, z Profesorem na czele, musieli badania te nie tylko prowadzić, ale i się ich uczyć. Chyba im wyszło nieźle, ale nie chcę tego oceniać.

Kolegiata stanowiła nowe wyzwanie. Od początku stało się jasne, że trzeba podjąć współpracę $\mathrm{z}$ architektami, konserwatorami architektury, historykami sztuki. Zapowiadała się jako trudna, choćby dlatego, że prof. J. Koszczyc-Witkiewicz, który był cały czas na miejscu, nie patrzył na archeologów przesadnie życzliwym okiem. Na szczęście, po jakimś czasie się do nich przekonał. Dlatego bardzo ważna była współpraca $\mathrm{z}$ grupą architektów i studentów z Zakładu Architektury Polskiej PW, kierowaną przez Zdzisława Tomaszewskiego (Poklewski 1993, 317).
Efektem tej współpracy były badania opactwa, którego relikty odkryto pod kolegiatą $\mathrm{i}$ ich publikacja. Wśród jej autorów jest Antoni Kąsinowski, brak natomiast Zdzisława Tomaszewskiego. On już nie mógł brać udziału w jej przygotowaniu, jednak, nawet dziś, po 56 latach od ukazania się jej drukiem, zalety pracy pozostają czytelne, choć np. dziś łatwiej byłoby opactwo ulokować wśród podobnych obiektów wczesnośredniowiecznej Europy - niewątpliwy znak czasu.

Szkoda, że nie doszło do opracowania wyników badań kolegiaty. Na szczęście jest praca T.H. Orłowskiego. Nikt, prócz niego, nie zdecydował się zając materiałami z badań z lat 50. XX w. - czekaja $\mathrm{w}$ archiwum łódzkiego ośrodka IAE PAN i w magazynach Muzeum w Łęczycy.

Natomiast podczas wykopalisk w kolegiacie jej badacze doszli do przekonania (może dziś już całkiem banalnego), które Tadeusz Poklewski tak sformułował (i kładł do głowy swoim uczniom):

„....istnieje czynnik, z którym powinien się liczyć każdy badacz przystępujący do zbadania in situ wszelkich materialnych pozostałości działania człowieka w przeszłości. Jest to oczywiście niepodzielność obiektu, która zmusza do jednolitości postępowania badawczego i dokumentacyjnego. Rozumiem to w ten sposób, że bez względu na rozmaitość elementów składających się na badany obiekt, postępowanie badawcze w stosunku do niego musi być jednolite i zwarte, operować jednym planem i we wszystkich przypadkach zamykać się w takich samych rygorach formalnych.

Łatwo podporządkować się tej zasadzie na jednorodnym i niezłożonym stanowisku archeologicznym w rodzaju cmentarzyska czy jednowarstwowej osadzie. Zdanie sobie sprawy z tej zasady jest jednak szczególnie ważne wówczas, gdy przystępuje się do badań obiektu zawierającego architekturę murowana, lecz wymagającego zastosowania archeologicznych metod badawczych. W takich wypadkach obiekt sugeruje rozdział na architekture murowaną i otaczające ją uwarstwienia ziemne. Wiemy, że rozdział to $\mathrm{z}$ gruntu fałszywy i to zarówno merytorycznie, jak i formalnie." (Poklewski 1975, 15).

I w innym miejscu:

„Należałoby rzeczywiście starać się stosować zasadę interdyscyplinarności badań, nie polidyscyplinarności! Rozumiemy tę interdyscyplinarność jako poddawanie tego samego, wydobytego z zie- 
mi prawidłowo przez archeologa źródła wspólnym interpretacjom i studiom przez przedstawicieli tych dyscyplin, dla których dzieło architektury historycznej jest przedmiotem zainteresowań podstawowym lub równorzędnym z innymi podobnymi, a więc przez archeologów, architektów, historyków sztuki, historyków budownictwa. Warto bowiem, a nawet należy, konfrontować możliwie szeroko wyniki własnych badań i własne ustalenia." (Poklewski 1987, 15).

\section{BIBLIOGRAFIA}

\section{Źródla}

Bulla z 1136 r. wyd. W. Taszycki. Najdawniejsze zabytki języka polskiego, „Biblioteka Narodowa” nr 104, Wrocław 1951, s. 75, w. 285-291.

\section{Literatura}

Adamczyk J. (ed.) 1997. Święty Wojciech i wejście Polski do Europy przed dziesięcioma wiekami. Łowicz.

Cybulska M., Kowalska-Pietrzak A., Kuberski S., Maik J., Orlińska-Mianowska E. 2011. Piętnastowieczna preteksta z herbem Korzbok z Archikolegiaty Łęczyckiej w Tumie. (W:) M. Żemigała (red.), 850 lat w stużbie Bogu i ludziom. Archikolegiata Łęczycka w Tumie. Materiaty z sesji naukowej $w$ Łęczycy dnia 21 maja 2011 roku. Łęczyca-Tum, 81-90.

Jażdżewski K. 1995. Pamiętniki. Wspomnienia polskiego archeologa $z X X$ w. Łódź.

Kajzer L. 1993. Zamki i społeczeństwo. Przemiany architektury i budownictwa obronnego $w$ Polsce $w$ X-XVIII w. Łódź.

Koss A. 2011. Prace konserwatorskie i restauratorskie w Archikolegiacie Łęczyckiej w latach 1995-2008. (W:) M. Żemigała (red.), 850 lat w stużbie Bogu i ludziom. Archikolegiata Łęczycka w Tumie. Materiaty z sesji naukowej $w$ Łęczycy dnia 21 maja 2011 roku. Łęczyca-Tum, 37-44.

Morawski Z. 2000. Sedes translata. Łęczyca na początku XII wieku. (W:) H. Manikowska, A. Bartoszewicz, W. Fałkowski (red.), Aetas media Aetas moderna. Studia ofiarowane profesorowi Henrykowi Samsonowiczowi w siedemdziesiata rocznice urodzin. Warszawa, 286-298.

Nadolski A. 2001. Łęczyca wczesnośredniowieczna w świetle źródeł archeologicznych. (W:) R. Rosin (red.), Łeczyca. Monografia miasta do 1990 r. Łęczyca, 73-88.

Nadolski A., Abramowicz A., Poklewski T., Kąsinowski A. 1960. Łęczyckie opactwo Panny Marii w świetle badań z lat 1954-56. Prace i Materiały Muzeum Archeologicznego i Etnograficznego w Lodzi. Seria archeologiczna 4, 5-93.
Orłowski T.H. 1983. Próba rekonstrukcji wnętrza romańskiej kolegiaty w Tumie pod Łęczycą z lat 1161-1294. Kwartalnik Architektury i Urbanistyki 28 (2), 91-118.

Pianowski Z. 1994. Sedes regni principales. Wawel i inne rezydencje piastowskie do połowy XIII wieku na tle europejskim. Kraków.

Pietrusińska M. 1971. Łęczyca - Tum. Relikty budowli, tzw. opactwo benedyktyńskie p.w. P. Marii, XI w. (?). (W:) M. Walicki (red.) Sztuka polska przedromańska i romańska do schyłku XIII wieku. M. Pietrusińska, Katalog i bibliografia zabytków. Warszawa, 731.

Poklewski T. 1975. Problemy merytoryczne i organizacyjne dokumentacji badań obiektów murowanych. Doświadczenia łódzkiego Zakładu Archeologii Polski Środkowej IHKM PAN, Biuletyn Informacyjny PKZ 31, 15-18.

Poklewski T. 1987 (1988). Możliwości poznawcze archeologii w badaniach architektury. Ocena archeologa. Wprowadzenie do dyskusji. Rocznik Przedsiębiorstwa Państwowego Pracownie Konserwacji Zabytków 1, 10-20.

Poklewski T. 1993. Początki współpracy badawczej archeologów i architektów. Casus kolegiaty w Tumie pod Łęczyca. Kwartalnik Architektury $i$ Urbanistyki 38 (3-4), 315-319.

Poklewski-Koziełł T. 1997. Abbatia sancte Marie in castello Lancicie. (W:) J. Adamczyk (red.), Święty Wojciech $i$ wejście Polski do Europy przed dziesięcioma wiekami. Łowicz, 69-83.

Poklewski-Koziełł T. 2002. Kościół Łęczycki, czyli budowle romańskie w Tumie. Blaski i cienie u początku Tysiąclecia. (W:) B. Solarski, M. Sęczkowska (red.), Pokłosie Zjazdu Gnieźnieńskiego. O poczatkach Kościoła $w$ Łęczycy. Łęczyca, 18-28.

Poklewski-Koziełł T. 2011. Archikolegiata NMP i św. Aleksego w Tumie pod Łęczycą - architektura w funkcji liturgii. (W:) M. Żemigała (red.), 850 lat w stużbie Bogu i ludziom. Archikolegiata Łęczycka w Tumie. Materiaty z sesji naukowej w Łęczycy dnia 21 maja 2011 roku. Łęczyca-Tum, 23-30.

Poklewski T., Puget W. Jaworowski H. 2001. Architektura na tle rozwoju przestrzennego miasta. (W:) R. Rosin 
(red.), Łęczyca. Monografia miasta do 1990 r. Łęczyca, 665-694.

Rozpędowski J. 1962. Ze studiów nad palatiami w Polsce. Biuletyn Historii Sztuki 24 (3-4), 243-254.

Sikora J. 2002. Uwagi na temat tzw. opactwa Panny Marii w Tumie pod Łęczycą. Kwartalnik Historii Kultury Materialnej 50 (3-4), 393-404.

Solarski B., Sęczkowska M. (eds.) 2002. Pokłosie Zjazdu Gnieźnieńskiego. O początkach Kościoła $w$ Łęczycy. Łęczyca.

Szymczak J. 2011. Pierwsze cztery wieki Archikolegiaty Łęczyckiej. (W:) M. Żemigała (red.), 850 lat w stużbie Bogu i ludziom. Archikolegiata Łęczycka w Tumie. Materiaty z sesji naukowej w Łęczycy dnia 21 maja 2011 roku. Łęczyca-Tum, 9-21.

Świechowski Z. 1990. Sztuka romańska $w$ Polsce. Warszawa.
Tomaszewski A.1997. Romański tum łęczycki. (W:) J. Adamczyk (red.) Święty Wojciech $i$ wejście Polski do Europy przed dziesięcioma wiekami. Łowicz, 61-67.

Zachwatowicz J. 1971. Architektura. (W:) M. Walicki (red.) Sztuka polska przedromańska i romańska do schytku XIII wieku. 69-194.

Żemigała M. (ed.) 2011. 850 lat w stużbie Bogu i ludziom. Archikolegiata Łęczycka w Tumie. Materiaty z sesji naukowej w Łęczycy dnia 21 maja 2011 roku. Łęczyca-Tum.

Żurowska K. 1983. Z problematyki genezy układu palatiów wczesnopiastowskich. (W:) K. Żurowska, Studia nad architekturq wczesnopiastowskq. Zeszyty Naukowe Uniwersytetu Jagiellońskiego 642, Prace z Historii Sztuki 17, 107-164.

\section{THE BEGINNINGS OF THE CATHOLIC CHURCH IN ŁECZYCA. EXCAVATIONS OF THE ABBEY AND THE COLLEGIATE CHURCH IN TUM}

\section{SUMMARY}

In the late 1940s large-scale archaeological excavations started across Poland. They were connected with the approaching $1000^{\text {th }}$ anniversary of the Baptism of Poland and therefore the rising of the Polish State (966-1966). As part of this programme the archaeological centre in Łódź (City Museum of Prehistory and the Chair of Prehistory at the University of Łódź), led by its founder, Prof. Konrad Jażdżewski, undertook excavations in Tum by Łęczyca, Gdańsk and Lutomiersk by Łódź.

The excavations in Tum had started in 1948, even before the Department for Studies on the Origins of the Polish State, an institution that was supposed to organise and coordinate the research, was officially established. The Administration of the Excavations in Łęczyca, initially directed by Prof. Konrad Jażdżewski but soon formally taken over by the Professor's student Andrzej Nadolski, was organised. When the Department for Studies on the Origins of the Polish State was changed into the Institute for the History of Material Culture of the Polish Academy of Sciences (presently the Institute of Archaeology and Ethnology of the Polish Academy of Sciences), the excavations in Łęczyca were conducted by its Department of Archaeology of Poland.

The research was conducted mainly at the early medieval stronghold in Tum, next to which the Romanesque collegiate church of St. Mary and St. Alexius is located.
The church was severely damaged during World War II, in September 1939. After that, in the 1940s and 1950s conservation works directed by Prof. Jan Koszyc-Witkiewicz were undertaken.

Conservation specialists and archaeologists started to cooperated very quickly, as a richly furnished bishop's grave was discovered in the church. Systematic excavations took place in 1954-1958.

Trenches took almost all of the surface of the central aisle, presbytery and both apses as well as partially side aisles, towers and defensive towers. Also, the closest neighbourhood of the church was excavated in some places.

During the excavations the researchers discovered an older stone building not related to the church walls and 176 graves. A number of discoveries which shed new light on the church's history were also made. The older building could have been associated with the St. Mary's Abbey mentioned in the Gniezno Bulla from 1136 where it was stated as follows: ...Item abbatia sancte Marie in castello Lancicie cum centum servis et villis eorum, cum quatuor scilicet lacubus: Pretche, Chotle, Bezdeze, Brdovo. It appears quite clear that this was a religious building, as it was made of stone, oriented and closed with an apse. However, the inner divisions suggest that these were apparently not relics of a church. 
The walls were build of fieldstones that were cladded with granite bricks from the outside and from the inside and with sandstone blocks in the corners, which means it was constructed in petit appareil. The rectangular building with an apse on the eastern side was divided into four rooms where the westernmost one was added later. The length of the structure without the extension was $21,6 \mathrm{~m}$, the width at the foundation level was $9,0 \mathrm{~m}$ and at the ground level $-7,20 \mathrm{~m}$.

As a sacred part of the abbey - a chapel - could have served the eastern room with an apse. The other ones could be a chapter house and a refectory. This means that a dormitory and the abbot's cell were not located on the ground floor. Because no basement was discovered and the walls are relatively thick, it is assumed that the building had at least two storeys. The monks' dormitories could have been located on the upper floor, or floors. The aforementioned extension, added on the West, is wider than the original structure, which suggests that on the southern side of the abbey there could have been a gallery or a corridor. The function of the room was not identified, not even hypothetically.

According to the researchers, the abbey was erected around 1000, which was a period of a dynamic development of the Church organisation in the Piast State and the monks were probably Benedictines. The scholars based their assumption on architectural analogies, especially the $10^{\text {th }}$ century St. Bavo's Abbey in Ghent, and a document issued by Otto III in 1001 in Ravenna where among other witnesses Anastasius abbas monasterii sancte Marie Sclavensis provinicie was mentioned. In Poland there was not enough room for two St. Mary's abbeys at that time.

In 1038, during the time of pagan rebellion and the Czech invasion of Poland, the abbey was probably abandoned. It is very unlikely that Łęczyca, located between Greater Poland devastated by the Czechs and the pagan Masovia survived this turmoil. The abbey could have been restored around 1075 when the restoration of the Gniezno metropolis took place. This would be the time when the abbey was extended - at least the fourth room in the western part of the building was added. The abbey definitively ceased to function when it became the property of the Gniezno archbishop around 1100. Since that time the abbey did not exist as an institution, however, the buildings remained and belonged to the archbishop, as the Gniezno Bulla says.

During the excavations no traces of destroying the abbey were found, quite the opposite, it seems that it was purposefully and systematically pulled down and the stones were used for the erection of the collegiate church.
The research on the history and architecture of the collegiate church was never fully published, as it was in the case of the abbey, however, it remained a matter of interest of its researchers, especially T. Poklewski, but also T.H. Orłowski, A. Tomaszewski and Z. Świechowski. They all referred to the fundamental monograph by $\mathrm{M}$. Walicki that was published before World War II.

The erection of the collegiate church started probably in the first half of the $12^{\text {th }}$ century or in the mid- $12^{\text {th }}$ century, possibly on the initiative of the Duchess Salomea who stayed in Łęczyca after the death of her husband, Bolesław the Wrymouth. The church could have also been founded either by one of Salomea's sons or the archbishop of Gniezno, Jakub of Żnin, or his follower Jan, called Janik. It seems likely because Łęczyca was a part of the archbishop's property at that time.

The consecration of the collegiate church, built as a votum for the victory over Władysław II the Exile, took place on $21^{\text {st }}$ May 1161. On this occasion King Bolesław the Curly organised a convention with political elite of his State, in which 4 dukes, 5 bishops and 26 noblemen mentioned by name participated.

The collegiate church is a three-aisled basilica without a transept yet with two apses (the eastern and the western ones), two towers in the western façade and two round defensive towers in the eastern façade. Side aisles with a matroneum are closed with apses from the East. The central aisle was covered with a ceiling, the presbytery - with a barrel vault and the small apses - with conches. The side aisles were covered with a cross-vault with no ribs and altars were placed in their apses. Also, in the central aisle there were two altars: St. Mary's and St. Alexius's ones. In the main portal located in the northern wall a sculpted tympanum that depicts the Adoration of the Virgin Mary with Child was placed, whereas in the western apse a painting of the Last Judgment was discovered.

After a fire and severe destructions after a Lithuanian invasion in 1294 the collegiate church was rebuilt in the second quarter of the $14^{\text {th }}$ century by the archbishop Jarosław Bogoria of Skotniki. The changes gave some Gothic character to the building. Further alterations from the $15^{\text {th }}, 16^{\text {th }}$ and $18^{\text {th }}$ centuries included some elements characteristic of the Gothic and the Baroque styles.

Conservation works conducted by Prof. Jan KoszycWitkiewicz were actually another reconstruction, during which the Romanesque and Gothic features of the building were restored. It was the effect of his vision and therefore the church acquired a form that it never had. Also, a number of mistakes were made, which resulted in a disastrous state of the church as soon as 40 years after the conservation process. 
This was the reason why a new modern conservation project was conducted in 1995-2008. It stopped the degradation of the walls, architectural details, sculptures and paintings, and restored the church to a condition that should allow for its further functioning.

Adres Autora:

Prof. dr hab. Jerzy Maik

Ośrodek Badań nad Dawnymi Technologiami Instytut Archeologii i Etnologii PAN

ul. Tylna 1

90-364 Łódź

e-mail: jotem4@wp.p1
The collegiate church is still a matter of interest for archaeologists, architects, historians, art historians and other scientists. It is hoped that it will remain one for a long time. 
